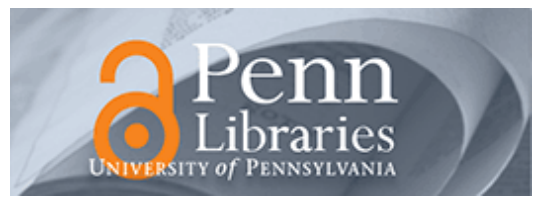

University of Pennsylvania

ScholarlyCommons

Accounting Papers

Wharton Faculty Research

8-2001

\title{
Stock Option Plans for Non-Executive Employees
}

John E. Core

Wayne R. Guay

University of Pennsylvania

Follow this and additional works at: https://repository.upenn.edu/accounting_papers

Part of the Accounting Commons

Recommended Citation

Core, J. E., \& Guay, W. R. (2001). Stock Option Plans for Non-Executive Employees. Journal of Financial Economics, 61 (2), 253-287. http://dx.doi.org/10.1016/S0304-405X(01)00062-9

This paper is posted at ScholarlyCommons. https://repository.upenn.edu/accounting_papers/103

For more information, please contact repository@pobox.upenn.edu. 


\title{
Stock Option Plans for Non-Executive Employees
}

\author{
Abstract \\ We examine determinants of non-executive employee stock option holdings, grants, and exercises for 756 \\ firms during 1994-1997. We find that firms use greater stock option compensation when facing capital \\ requirements and financing constraints. Our results are also consistent with firms using options to attract \\ and retain certain types of employees as well as to create incentives to increase firm value. After \\ controlling for economic determinants and stock returns, option exercises are greater (less) when the \\ firm's stock price hits 52-week highs (lows), which confirms in a broad sample the psychological bias \\ documented by Heath et al. (Quarterly Journal of Economics 114 (1999) 601-628). \\ Keywords \\ compensation and incentives, financing, employees, non-executives, stock options \\ Disciplines \\ Accounting
}




\section{STOCK OPTION PLANS FOR NON-EXECUTIVE EMPLOYEES}

First draft: September, 1999

Current draft: October, 2000

\author{
John Core \\ The Wharton School \\ University of Pennsylvania \\ 2400 Steinberg-Dietrich Hall \\ Philadelphia, PA 19104-6365 \\ (215) 898-4821 \\ jcore@wharton.upenn.edu
}

\author{
Wayne Guay \\ The Wharton School \\ University of Pennsylvania \\ 2400 Steinberg-Dietrich Hall \\ Philadelphia, PA 19104-6365 \\ (215) 898-7775 \\ guay@wharton.upenn.edu
}

The helpful comments of Stan Baiman, Phil Berger, Peggy Bishop, Gus DeFranco, Nick Gonedes, S.P. Kothari, Andy Leone, Lisa Muelbrook, Ram Natarajan, Jun Qian, Madhav Rajan, Ross Watts, Jerry Zimmerman, an anonymous referee, seminar participants at the Massachusetts Institute of Technology, Northeastern University, the University of British Columbia, the University of Michigan, the University of Rochester, the University of Wisconsin, the Wharton School, the 2000 American Accounting Associaton conference, and the 2000 European Finance Association conference are gratefully acknowledged. We appreciate the research assistance of Irina Faykina, Nazgol Ghandoosh, Scott Mooney, and Christine Phillips, and gratefully acknowledge the financial support of the Wharton School. 


\title{
STOCK OPTION PLANS FOR NON-EXECUTIVE EMPLOYEES
}

\author{
Abstract \\ We examine determinants of non-executive employee stock options outstanding, grants, \\ and exercises for 756 firms during 1994 to 1997 . We find that firms use greater stock option \\ compensation when facing capital requirements and financing constraints. Our results are also \\ consistent with firms using options to attract certain types of employees, provide retention \\ incentives, and create incentives to increase firm value. After controlling for economic \\ determinants and stock returns, option exercises are greater (less) when the firm's stock price hits \\ 52-week highs (lows), which confirms in a broad sample the psychological bias documented by \\ Heath, Huddart, and Lang (1999).
}




\section{Introduction}

The corporate use of stock option plans for non-executive employees is widespread and growing. A 1999 survey by William M. Mercer reported in USA Today finds that the percentage of large firms granting stock options to at least half of their employees increased steadily from $17 \%$ in 1993 to $39 \%$ in 1999. In some companies, stock options are used so extensively that institutional shareholders have begun recently to refuse approving increases in the number of shares available for options. While option grants to CEOs have received considerable attention in the literature, there has been no large-sample research on option plans for non-executive employees. ${ }^{\square}$ e contribute to the literature on corporate option plans by describing a large sample of non-executive option plans, and examining the determinants of i) non-executive option holdings, ii) grants of options to non-executives, and iii) non-executive option exercises.

In a broad sample of 756 firms with option plans during the years 1994 to 1997, we find that options are granted extensively to non-executive employees. We define non-executive employees as all employees other than the five most highly compensated executives, as identified in the proxy statement. On average, the number of options outstanding to all employees exceeds $6.9 \%$ of shares outstanding. Non-executive employees hold $67 \%$ of these options, although this percentage varies substantially across our sample firms. On a peremployee basis, the mean (median) firm's non-executive employees hold option portfolios valued at over $\$ 17,000(\$ 3,000)$.

Following previous literature on CEO option plans (e.g., Yermack, 1995; Core and Guay, 1999a), we investigate the hypothesis that options are used to provide both incentives and

\footnotetext{
${ }^{1}$ Existing research on equity compensation to non-executive employees includes Huddart and Lang (1996), who examine option exercise behavior of 50,000 non-executive employees at eight corporations, and Frye (1999), who finds an association between Tobin's $\mathrm{q}$ and the proportion of total employee compensation that is equity compensation for a panel of 326 firm-year observations from 1992 to 1994.
} 
compensation. To understand the dynamics underlying these plans, we explore both the level of options held by employees and the flow of options into the plan via grants of new options and out of the plan via option exercises. If firms use options to attract and retain employees, or to provide employees with incentives to increase firm value, we expect that the level of options held by employees varies predictably with firm characteristics. To test this hypothesis, we develop a cross-sectional model for the level of option incentives held by non-executive employees based on theory and empirical work on the distribution of equity incentives within and across organizations (e.g., Demsetz and Lehn, 1985; Jensen and Meckling, 1992; Smith and Watts, 1992; Bushman, Indjejikian, and Smith, 1995).

We hypothesize that firms grant new options to non-executive employees both as a substitute for cash compensation and to adjust aggregate incentive levels. Because option grants require no contemporaneous cash payout, we expect that a firm substitutes grants of options for cash compensation when it needs cash and when its external financing is relatively more costly. Further, we predict that firms make grants of new option incentives when the level of options outstanding provides insufficient incentives, and that grants of incentives are positively related to contemporaneous exercises of option incentives. We model new grants of options and option exercises as a system of simultaneous equations to reflect their expected interdependencies. We hypothesize that option exercises are a function of economic factors related to employee riskaversion, such as the amount of risk imposed on employees through previously granted and newly granted options, and to psychological factors related to employees using 52-week highs and lows as reference points (Heath, Huddart, and Lang, 1999).

Our empirical results strongly support the hypothesis that options are granted to nonexecutives more intensively when firms have greater financing needs and face financing 
constraints. Further, we find support for our hypothesis that the level of options outstanding is related to economic determinants of firms' use of equity incentives. However, we find mixed evidence that firms actively manage the level of non-executive option incentives through annual grants. Finally, our evidence strongly supports that option exercises are influenced by economic factors related to employee risk-aversion, and by the psychological reference point bias documented by Heath, Huddart, and Lang (1999), who use longitudinal exercise data from seven firms.

The remainder of this paper is organized as follows. In Section 2, we describe our hypotheses with respect to the level of option holdings, grants of options, and option exercises. We describe the data in Section 3, present the results of our empirical tests in Section 4, and conclude in Section 5.

\section{Hypothesis development}

Our primary hypothesis is that firms grant options to non-executive employees to provide equity incentives, to attract and retain certain types of employees, and as a substitute for cash compensation. To test the hypothesis that firms use non-executive option plans to provide equity incentives and employee-retention incentives, we first develop a cross-sectional model of the economic determinants of option incentives. We define equity incentives from options as the change in the optionholder's wealth for a one-percent change in shareholder value. To examine the use of stock options in compensating non-executive employees, as well as to explore further the role of options in providing equity incentives to non-executives, we model new grants of options and option exercises as a system of simultaneous equations to reflect their interdependencies. We summarize our predictions in Table 1, and discuss the theoretical and empirical support for our predictions in the following sub-sections. 


\subsection{The level of options outstanding}

Theory and empirical findings suggest that executive contracts implicitly or explicitly require that executives hold equity incentives (Demsetz and Lehn, 1985; Himmelberg, Hubbard, and Palia, 1999). For non-executive employees, it is less clear whether firms use options for incentive purposes because the ability of lower-level employees to influence the stock price through their individual actions is limited. However, the use of stock options potentially induces mutual monitoring and thereby improves group incentives. Further, because employees generally are required to exercise their options at the time of departure, thereby forcing suboptimal early exercise, firms use options to retain employees (Hale, 1998). The retention incentive is reinforced by the fact that options commonly have a vesting period of two to three years (Kole, 1997). Finally, the commitment by firms to require employees to hold options can serve to attract certain types of employees, such as employees with low risk-aversion.

We predict that firms provide equity incentives more intensively to non-executives when direct monitoring of employees is costly. Direct monitoring of lower-level employees is expected to be more costly when the firm is larger and more decentralized, when there is greater noise in the firm's operating environment, and when the firm has greater growth opportunities (Demsetz and Lehn, 1985; Jensen and Meckling, 1992; Smith and Watts, 1992). Because there are likely to be economies of scale in monitoring, the need for equity incentives is expected to increase at a decreasing rate with firm size. On the other hand, in large firms, lower-level employees are less likely to be able to influence stock price through their individual actions. Thus, the expected relation between firm size and the use of stock options to provide incentives is ambiguous. We use the logarithm of the market value of assets (measured as the sum of the market value of 
equity and the book value of liabilities) and the number of employees as proxies for decentralization and firm size.

Similar to Demsetz and Lehn (1985), we use the logarithm of idiosyncratic risk as a proxy for noise in the firm's operating environment. The logarithmic transformation captures Demsetz and Lehn's prediction that, because of risk aversion, equity incentives will increase at a decreasing rate with noise. We measure idiosyncratic risk as the standard deviation of the residual return from a 36-month market model regression. Following Smith and Watts (1992), we use the book value of assets divided by the market value of assets as a proxy for growth opportunities and expect that firms with greater growth opportunities have lower book-to-market ratios. We also use the three-year average of research and development expense scaled by assets as an additional measure of growth opportunities.

The prevalence of vesting periods for options and the requirement that employees immediately exercise options when they leave the company suggests that firms use options to retain employees. We predict that the importance of retaining employees is greatest in firms requiring higher quality managers and in firms where human capital is a relatively more important factor of production. Smith and Watts (1992) hypothesize that firms with substantial growth opportunities require higher quality managers, and Core and Qian (2000) predict that lower-level employees receive more options at firms where growth opportunities are more strongly related to human capital. As described above, we use the book-to-market ratio and research and development expense scaled by assets to capture growth opportunities. As a proxy for the importance of human capital, we use the amount of growth options per employee, which we define as (market value of equity minus book value of equity) divided by the number of employees. The predicted positive relation between growth opportunities and the use of stock 
options is reinforced if firms with risky growth options also seek to attract employees that are relatively less risk-averse, since highly risk-averse workers are likely to avoid companies that tie a substantial proportion of their wealth to stock price.

Bushman, Indjejikian, and Smith (1995) argue that interdependencies among operating units increase the usefulness of aggregate performance measures in evaluating lower-level managers. They predict that interdependencies, and therefore aggregate performance measures, decrease with product-line and geographic diversification, and increase with sales between segments. Their findings are consistent with these predictions. ${ }^{6}$ Because stock options tie employee wealth to aggregate firm performance, we expect that equity incentives from stock options are negatively associated with corporate diversification and positively associated with sales between segments.

Following Bushman, Indjejikian, and Smith (1995), we use two entropy measures of diversification. Total product diversification is calculated from data on the Compustat Industry Segments File and is equal to $\Sigma P_{i} \ln \left(1 / P_{i}\right)$, where $P_{i}$ is dollar sales of principal product $i$ scaled by total firm sales. Geographic diversification is calculated from data on the Compustat Geographic Segments File and is equal to $\Sigma G_{i} \ln \left(1 / G_{i}\right)$, where $G_{i}$ is dollar sales for geographic segment $i$ scaled by total firm sales. We use intersegment sales scaled by total net sales to measure interdependencies between firms' segments.

In addition to the systematic economic determinants of options use described above, we also expect that there exist firm-specific determinants of options use. To control partially for these determinants, we include a measure of the intensity with which firms use options for top executives. We predict that firms use non-executive options more intensively in business

\footnotetext{
${ }^{2}$ Keating (1997) predicts a more complex relation between division interdependencies and equity-based compensation, but finds no evidence of this relation.
} 
environments where options are particularly useful in monitoring top management. We measure the intensity of options use for top executives as the residual from a regression of top-five executives' equity incentives from options on size, growth opportunities (book-to-market and R\&D expense), and idiosyncratic risk. The option intensity variable also helps to control for alternative incentive mechanisms that firms use as substitutes for employee stock options, which we cannot observe or measure as precisely as we can the use of stock options.

Finally, we include 22 industry indicator variables in the specification to control for

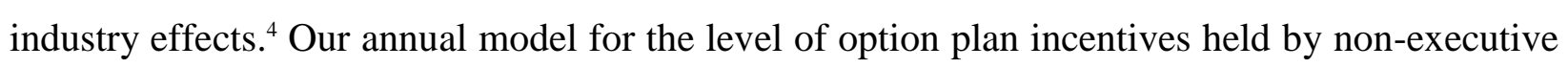
employees is summarized as:

$$
\begin{aligned}
& \text { Option plan incentives } \mathrm{it}_{\mathrm{i}-1}=\beta_{0}+\beta_{1} \log (\text { market value of assets })_{\mathrm{it}-1} \\
& +\beta_{2} \log (\# \text { of employees })_{\mathrm{it}-1} \\
& +\beta_{3} \log (\text { Idiosyncratic risk })_{\mathrm{it}-1}+\beta_{4} \text { Book-to-market } \mathrm{t}_{\mathrm{it}-1} \\
& +\beta_{5} R \& D_{i t-1}+\beta_{6} \text { Growth options per employee } e_{i t-1} \\
& +\beta_{7} \text { Total diversification }_{\mathrm{it}-1}+\beta_{8} \text { Intersegment sales }_{\mathrm{it}-1} \\
& +\beta_{9} \text { Geographic diversification }{ }_{\mathrm{it}-1} \\
& +\beta_{10} \text { Top } 5 \text { option residual } \mathrm{it}_{\mathrm{i}-1} \\
& +\beta_{11} \text { Industry controls } \mathrm{it}-1+\varepsilon_{\mathrm{it}-1}
\end{aligned}
$$

\subsection{Option grants}

We hypothesize that firms grant new options to non-executive employees both as a substitute for cash compensation and to make adjustments to aggregate incentive levels. Because grants of equity require no contemporaneous cash payout, firms with cash constraints are expected to use these forms of compensation as a substitute for cash pay (Yermack, 1995; Dechow, Hutton, and Sloan, 1996). Because employees are risk-averse and have relatively short investment horizons, workers are expected to require a risk premium to accept equity

\footnotetext{
${ }^{3}$ In sensitivity tests described below, we show that our results are robust to including indicator variables for two common forms of alternative equity incentive mechanisms: the existence of a restricted stock plan and the existence of an employee stock ownership plan.

${ }^{4}$ To generate reasonable estimates for the indicators, we combine 59 two-digit SIC codes into 23 industry groups. Our results are robust to instead including 58 two-digit SIC code indicators.
} 
compensation in lieu of cash. However, the value of the tax deferral that employees receive from stock compensation can reduce this premium. In addition, provided that the information asymmetries between the firm and its employees are lower than those between the firm and outside investors, equity compensation can have cost advantages relative to external equity financing. We expect that equity compensation is substituted for cash pay by companies with cash constraints, high capital needs, high costs of accessing capital markets, and a relatively greater interest in attracting less risk-averse workers.

We proxy for cash constraints with measures of cash flow shortfall and interest burden. We define cash flow shortfall as the three-year average of [(common and preferred dividends + cash flow used in investing activities - cash flow from operations)/total assets]. Interest burden is the three-year average of interest expense scaled by operating income before depreciation. To mitigate the influence of a discontinuity in interest burden at zero, we set interest burden equal to one for the $3.5 \%$ of our sample firms with interest expense greater than operating income before depreciation (i.e., where interest expense is positive and operating income is either negative, or positive but less than interest expense). Our proxies for capital needs and cost of accessing capital markets are the book-to-market ratio and R\&D expense as defined in Section 2.1. We also include a long-term debt indicator variable. Firms that have been unable to secure long-term debt are expected to be substantially constrained with respect to the debt markets.

Another motivation for substituting stock option compensation for cash compensation is the reduced impact of compensation on earnings, that is, cash compensation is expensed whereas the value of stock option grants is disclosed in the footnotes to the financial statements. Thus, we

\footnotetext{
${ }^{5}$ We use three-year average values for several of the explanatory variables in our grant and exercise regressions because we expect that firm policy on granting options is persistent, and does not vary with short-term fluctuations in the hypothesized determinants.
} 
expect that firms with earnings constraints grant more stock options, ceteris paribus. Because interest burden restrictions are a very common covenant in debt agreements, we expect that in addition to being a proxy for cash constraints, this variable is also a proxy for earnings constraints.

We control for the marginal tax rate as a potential determinant of option grants (Yermack, 1995; Matsunaga, 1995; Dechow, Hutton, and Sloan, 1996; Hall and Liebman, 2000). When future corporate tax rates are expected to be higher, the future tax deduction from deferred compensation becomes more favorable relative to the immediate tax deduction received from cash compensation. Therefore, ceteris paribus, the use of stock-based compensation is expected to be less costly for firms with low marginal tax rates. To capture variation in firms' marginal tax rates, we use two indicator variables. The first variable (Low marginal tax) equals one if the firm has negative taxable income and net operating loss carry-forwards in each of the previous three years, and zero otherwise. The second variable (High marginal tax) equals one if the firm has positive taxable income and no net operating loss carryforwards in any of the three previous years, and zero otherwise. Plesko (1999) finds that this classification of firms into low, medium

\footnotetext{
${ }^{6}$ From the employee's perspective, deferred compensation such as restricted stock and options always provides a higher after-tax return (before adjusting for risk) than a cash payment of equal value because taxes on the return are deferred (Miller and Scholes, 1980; Smith and Watts, 1982). If an option is non-qualified (tax-qualified under Internal Revenue Code Section 422), the employee's gain is taxable on exercise (on sale of stock) as ordinary (capital gains) income.

With a qualified option, the firm receives no tax deduction. For non-qualified options, the firm receives a deduction at the time of exercise (for options that are disqualified when the employee sells the stock within one year of exercise, the firm receives a deduction at the time of sale). Although we are unable to distinguish between qualified and non-qualified options in our sample, the tax costs of non-qualified (qualified) options relative to cash compensation are expected to be less (at least as small) for low-tax firms. Further, it seems likely that many employees forfeit the tax benefits of qualified options granted by our sample firms by not holding the stock obtained through exercise. This follows from the observation that early exercise is frequent in our sample, and that it would not be rational for an employee to exercise a qualified option early unless he or she expects to sell the stock immediately.
} 
(in the intercept), and high marginal tax rates performs nearly as well as more complex proxies for marginal tax rates.

If firms use options as a substitute for cash compensation in a fixed proportion, total compensation and option grants are expected to be greater when firm performance is stronger. Empirical examinations of CEO option grants tend to find a positive association between grant levels and contemporaneous performance (e.g., Baber, Janakiraman, and Kang, 1996; Janakiraman, 1998; Core and Guay, 1999a). There is also anecdotal data that firms grant options to reward performance. For example, General Electric Company grants options to lower-level employees with above-average performance evaluations, but only when the entire firm has performed well (Hymowitz and Murray, 1999). We use current year and previous year stock returns as proxies for firm performance.

In addition to using options as a substitute for cash compensation, we expect that when firms use options to provide non-executive employees with incentives and/or to attract and retain employees, deviations from target incentive levels influence the magnitude of new option grants. Core and Guay (1999a) find that option grants to CEOs are negatively related to deviations from target incentive levels. We use Equation (1), described in Section 2.1, to estimate the target level of non-executive option incentives as a function of firm size, monitoring difficulty, growth opportunities, decentralization, and the importance of human capital. We use the residuals from individual annual estimations of this cross-sectional model to estimate the extent to which a given firm's existing level of option incentives is above or below their target level. Under the joint hypothesis that firms seek to maintain a target level of option incentives for their nonexecutive employees, and that Equation (1) fully captures the determinants of this target level, 
we expect a negative relation between the residuals estimated at the end of year $t-1$ and the option incentives provided by new grants in the following year $t$.

If Equation (1) fails to capture important firm-specific determinants of option plan levels, and the omitted determinants are uncorrelated with future option grants, the expected negative correlation between the residuals estimated at year $t-1$ and option incentives granted in year $t$ will be biased toward zero. Alternatively, if the same important firm-specific determinants of nonexecutive option plans are omitted from both Equation (1) and our model of option incentives granted in year $t$, a positive correlation can be induced between the residuals estimated at year $t-1$ and option incentives granted in year $t$.

Option exercises decrease the level of option incentives outstanding. Therefore, we expect that if firms manage option incentives around a target level, greater grants of options are made during years when option exercises are greater. Note that this argument does not imply that employees have perverse incentives to exercise options solely for the purpose of inducing larger option grants. Assuming that the level of an employee's compensation is determined by market forces, as option compensation increases, firms will substitute away from other forms of compensation, such as cash pay. Because we argue below in Section 2.3 that grants of options also are expected to be a determinant of exercises, we model grants and exercises as a system of simultaneous equations. Janakiraman (1998) documents a simultaneous relation between annual option grants and exercises by CEOs, in which larger exercises lead to larger grants. We also include $\log$ (sales) and $\log$ (number of employees), in conjunction with the industry controls, to control for the industry-mean compensation expense as a fraction of sales.

\footnotetext{
${ }^{7}$ We cannot control for compensation expense directly because this variable is not reported on Compustat for $75 \%$ of our firms. Further, because this Compustat item tends to be reported most frequently by low-growth industries such as utilities, it is subject to substantial selection bias.
} 
The foregoing arguments suggest the following model for option grants to non-executive employees, in which option grants are measured during year $t$ and, with the exception of current year stock return and option exercises, the determinants of option grants are measured at the end of year $t-1$ :

Grants of option incentives ${ }_{i t}=\beta_{0}+\beta_{1}$ Cash flow shortfall $_{\text {it- } 1}+\beta_{2}$ Book-to-market $_{\text {it- } 1}$

$$
\begin{aligned}
& +\beta_{3} \text { R\&D }_{\mathrm{it}-1}+\beta_{4} \text { Long-term debt indicator }_{\mathrm{it}-1} \\
& +\beta_{5} \text { Interest burden }_{\mathrm{it}-1}+\beta_{6} \text { Low marginal tax }_{\mathrm{it}-1} \\
& +\beta_{7} \text { High marginal tax }_{\mathrm{it}-1}+\beta_{8} \text { Stock return }_{\mathrm{it}} \\
& +\beta_{9} \text { Stock return }_{\mathrm{it}-1}+\beta_{10} \text { Incentive residual }_{\mathrm{it}-1} \\
& +\beta_{11} \text { Incentives exercised }_{\mathrm{it}} \\
& \left.+\beta_{12} \text { Log }_{(\text {sales }}\right)_{\mathrm{it}-1}+\beta_{13} \log (\# \text { of employees })_{\mathrm{it}-1} \\
& +\beta_{14} \text { Industry controls }_{\mathrm{it}-1}+\mathrm{u}_{\mathrm{it}}
\end{aligned}
$$

\subsection{Option exercises}

Huddart and Lang (1996) and Heath, Huddart, and Lang (1999, hereafter, HHL) examine the determinants of option exercise using samples of 5,060 monthly observations on eight firms, and 12,145 weekly observations on seven firms, respectively. We use their findings as a basis for testing predictions about option exercise for our sample of 1,264 years of exercise data on 568 firms. Compared to their data, our sample is more aggregated and we do not have information on individual grants or on the individuals holding the grants. On the other hand, we have a much larger and broader sample of firms, and we can control for grants made concurrently as a possible determinant of exercise.

Economic models such as Lambert, Larcker, and Verrecchia (1991) and Huddart (1994) predict that risk-averse employees exercise early and are more likely to exercise early when a greater proportion of their wealth is tied to the stock price. It is costly to exercise options early because it involves forfeiting the time value of the option. Accordingly, we follow HHL and predict that option exercises are greater when the realizable value of an employee's options is a 
larger fraction of the options' Black-Scholes value. As a proxy for this fraction, we estimate, for each firm-year, the total realizable value of non-executives' option holdings divided by the Black-Scholes value of these holdings. This variable is equal to the difference between beginning of year stock price and the average exercise price of the options held at the beginning of the year, divided by the estimated beginning of the year Black-Scholes value per option held. The measure takes on a value close to one when most of the employees' options are deep-in-the money, and takes on negative values when the options are out-of-the money. ${ }^{[}$Because employees' exercise decisions are made at the individual grant level, as opposed to a portfolio level, this proxy contains more measurement error when exercise prices are more heterogeneous across the options in a firm's option plan. Consistent with the intuition in Vargus (1998), we also predict that risk-averse employees exercise more options to rebalance their portfolios when they hold more options at the beginning of the year, as measured by the residual from Equation (1), and when they receive higher grants during the year.

HHL predict and find that option exercises are related to psychological factors that are hard to explain within the context of rationality. They document two separate psychological biases, one related to individuals' beliefs that short-term trends in stock returns reverse ("beliefs"), and the second related to individuals' tendency to set reference points with respect to stock price highs and lows ("reference points").

HHL's beliefs story is based on experimental findings that individuals believe that shortterm price trends (as proxied by the returns four weeks and six months prior to exercise) will reverse, and that long-term price trends (as proxied by returns for the six-month period ending

\footnotetext{
${ }^{8}$ Because the Black-Scholes value of an option approaches zero as the stock price drops further below the exercise price, the realizable value ratio can take on large negative values. However, all of our results are robust to setting negative values of this ratio equal to zero.
} 
six-months before exercise) will persist. We are unable to conduct a powerful test of the HHL belief hypothesis because we have data on annual (not weekly) exercises, and we do not have data on the portion of the option portfolio that is exercisable. Therefore, we include the stock return for the current year and previous year in our model of exercises, but do not predict the direction of the association.

HHL's second prediction is that option holders set reference points with respect to stock price levels over the previous year. In support of this prediction, they find strong and robust evidence that option exercises increase immediately following the time that the current stock price exceeds its previous 52-week high. Assuming that greater exercises following price increases can be rationalized, the fact that the stock price exceeds a 52-week high conveys no marginal information and should have no explanatory power. We operationalize HHL's prediction within our data by predicting that total annual option exercises is an increasing function of the number of months within that year that the stock price hit a 12-month high. For example, because we expect an increase in exercises each month that the stock hits a 52-week high, we expect more exercises if the stock hits 52-week highs in 9 of the 12 months, than if it hits highs in 3 of the 12 months. We also extend HHL's hypothesis by predicting the corollary that option exercises are a decreasing function of the number of months within the current year that the stock price hits a 12-month low. We compute these variables using CRSP monthly closing prices. Each of the variables has a potential range from 0 to 12 .

Last, we examine whether the amount of options exercised by non-executive employees predicts future returns. For a sample of top-level executives, Vargus (1998) finds that currentyear exercises are negatively associated with the following year's returns. If non-executive employees have private information about the firm's prospects, they are likely to be able to trade 
on this information more easily and more discretely than executives, who are subject to more extensive disclosure requirements. We include the return over the year following exercise in our model, and predict that this variable is negatively associated with option exercises if employees have private information about firm value.

We include $\log$ (sales) and $\log$ (number of employees) in our specification to control for size. Based on the prior analysis, we estimate the following model for option exercises by nonexecutive employees:

Exercise of option incentives $_{\text {it }}=\beta_{0}+\beta_{1}$ Incentive residual $_{\mathrm{it}-1}+\beta_{2}{\text { Incentives } \text { granted }_{\mathrm{it}}}$ $+\beta_{3}$ Fraction of $\mathrm{BS}$ value realizable $\mathrm{it}_{1}+$ $+\beta_{4}$ Number of price highs ${ }_{i t}+\beta_{5}$ Number of price lows $s_{i t}$ $+\beta_{6}$ Stock return $_{\mathrm{it}+1}+\beta_{7}$ Stock return $_{\mathrm{it}}+\beta_{8}$ Stock return $_{\mathrm{it}-1}$ $+\beta_{9} \log (\text { sales })_{\mathrm{it}-1}+\beta_{10} \log (\# \text { of employees })_{\mathrm{it}-1}$ $+\beta_{11}$ Industry controls $\mathrm{s}_{\mathrm{it}-1}+\mathrm{u}_{\mathrm{it}}$

\section{Sample and variable measurement}

In this section, we describe our sample selection process and the data we use to test our hypotheses. We use data from four sources. From the firms' 1997 10-Ks, we obtain data on firmwide option grants and exercises for 1995, 1996, and 1997, and data on options outstanding for 1994, 1995, 1996, and 1997. We obtain data on the top-five executives' option holdings and option grants from the Standard and Poor's Execucomp database. We use CRSP data to generate measures related to stock price performance, stock-return volatility, and treasury bond yields. Compustat is our source for firms' financial data and industry classifications.

\footnotetext{
${ }^{9}$ Our measure of stock options includes stock appreciation rights (SARs) that are issued in tandem with stock options. SARs have the same payout structure as options, except that upon exercise, the holder receives the excess of the stock price over the exercise price in cash. A tandem SAR is paired with a stock option with the same terms, and the exercise of the SAR (option) cancels the related option (SAR). Our measure of stock options does not include freestanding SARs (SARs with no attached stock option), as there is no required disclosure on non-tandem SARs. While such an omission causes error in our measure of option incentives, this error is likely to be small; non-tandem SARs are rarely used because they have a higher accounting expense than tandem SARs and no countervailing benefit.
} 


\subsection{Sample selection}

We obtain an initial sample of 1,059 firms from the Execucomp database. We remove firms from this initial sample if the firms are banks (SIC 6000-6199), or if the firms have missing 10-K, CRSP or Compustat data. We exclude firm-years when a target company's option plan is merged into the option plan of an acquirer. We also remove firm-years in which a company makes an acquisition using the pooling of interests method, and all firm years prior to this acquisition, because the pooling method combines the acquirer's and target's options for all years before and including the acquisition year. We remove firm-years in which the $10-\mathrm{K}$ data on aggregate options and exercise prices does not match with the Execucomp data on total options and exercise prices for the top-five executives. ${ }^{0}$ Finally, we remove firm-years that have no options outstanding.

The resulting sample consists of 756 firms and 2,349 firm-years of observations on options outstanding for fiscal years 1994 to 1997. Panel A of Table 2 summarizes the option plans. On average, the total number of options outstanding to all employees is $6.9 \%$, with a range from just over $0 \%$ up to $37 \%$. Non-executive employees hold $66.9 \%$ of all outstanding options. However, this percentage varies substantially across the sample firms, with a standard deviation of $18.7 \%$ and a range of nearly $100 \%$. The magnitude of the non-executive option plans is also

\footnotetext{
${ }^{10}$ Examples of this lack of match occur when options held by the top-five executives are greater than total options outstanding, or when the exercise price of executive stock options is greater (lower) than the high (low) price for the year. Examples of reasons for lack of match with the Execucomp data include missing Execucomp data, coding errors in Execucomp, firms attributing grants made after the fiscal year-end to the current fiscal year, and the fact that reported option grants to top-five executives include grants of options on subsidiary stock made to the top-five executives. Note that our measure of optionholdings is upwardly biased in some cases where top-five executives receive grants of options on subsidiary stock. This is because we can only filter out this problem when the number of options held by the top-five executives is greater than total options outstanding.

${ }^{11}$ Approximately $8 \%$ of the firm-years do not have option plans. By conducting our analysis only on firms with option plans, we risk introducing a sample selection bias into our data. To address the possibility of such a bias, we follow Heckman (1979) and estimate a probit model for firms' choice of whether to use options, and include the inverse Mills ratio as an additional regressor. All of our results are robust to including the inverse Mills ratio. For parsimony and for ease of exposition, we report results from OLS regressions.
} 
substantial on a per employee basis. The mean (median) firm's non-executive employees hold option portfolios worth $\$ 17,296(\$ 3,143)$.

Panel B of Table 2 provides a breakdown of the non-executive option plans into 23 industry groupings. Column 1 reports the distribution of the sample firms across industries and indicates that no single industry contains more than $10 \%$ of the sample. Columns 2 through 5 describe the median characteristics of the option plans. In Column 2, the overall size of the option plans (including options held by top-five executives and non-executives) range from $1.8 \%$ of shares outstanding for the utilities, to $11.3 \%$ and $14.4 \%$ for the pharmaceutical companies and computer companies, respectively, with most of the industries clustering between $4 \%$ and $7 \%$. The fraction of options outstanding held by non-executives ranges from $55.2 \%$ to $83.0 \%$, and is reported in Column 3. Column 5 indicates that there is substantial variation across industries with respect to option portfolio value per employee. For the median utility firm, the average employee holds an option portfolio valued at \$747. In contrast, for the median computer and drug company, the average per employee option portfolio value is much larger at $\$ 23,218$ and $\$ 49,103$, respectively. While the differences across industries are large, we expect that a considerable amount of this variation can be explained by the firm characteristics modeled in Equation (1). We explore this expectation further in Section 4.1.

To estimate our model for the level of options use at time $t-1$, we use the subsample of 696 firms and 1,694 firm-years with data on options outstanding for fiscal years 1994 to 1996. For our analysis of option grants and exercises, we delete firm-years for which data is not available to construct our explanatory variables, and firm-years in which option repricings took place. Of the resulting sample of 1,615 observations, 285 firm-years are deleted because year $t-1$ data on the option residual or the fraction of the Black-Scholes value realizable is missing. After 
deleting firms for which the option grant or exercise is zero, the sample consists of 1,263 firmyears with non-zero values for both grants and exercises during fiscal years 1995-1997.

\subsection{Measures of option incentives and option compensation}

We define option incentives as the change in the dollar value of the holder's options for a $1 \%$ change in the stock price. Consistent with prior research by Jensen and Murphy (1990), Yermack (1995), and Hall and Liebman (1998), we estimate the sensitivity of an option's value to the stock price as the partial derivative of option value with respect to price (the option "delta"). Like this prior research, we assume that the appropriate risk-neutral valuation for an employee stock option is given by the Black-Scholes (1973) model, as modified by Merton (1973) to account for dividend payouts. The delta for a typical, newly granted, long-term executive stock option is approximately 0.75 , which means that the option value increases by $\$ 0.75$ when the stock price increases by $\$ 1.00$. To transform this option delta into the dollar change in the value of the option for a $1 \%$ change in the stock price, we multiply the option delta by $1 \%$ of the firm's stock price.

When we compute the option delta, we face the problem that the grant and exercise data are aggregated over the year and reflect an average exercise price over the year. This aggregation is not expected to introduce substantial error into our calculations as the delta calculated using

\footnotetext{
${ }^{12}$ The requirement that we have year $t-l$ data raises the possibility of a sample selection bias that potentially effects our estimation of Equations (2) and (3). However, when we model the selection and include the inverse Mills ratio as an additional regressor, all of the results reported in Tables 7 and 8 are robust to its inclusion.

${ }^{13}$ We acknowledge that the Black-Scholes model produces a biased measure of option value in this setting because employee stock options do not satisfy the assumptions of standard option pricing models (i.e., a risk-neutral holder, no vesting period, and the ability to transfer the option to another party). These features of employee stock options are generally believed to induce early exercise. As such, a more accurate description of our empirical methods is that we use the Black-Scholes model to produce an instrumental variable to capture cross-sectional variation in option plan delta. It is also important to note that our estimate of option plan delta is likely to be a relatively unbiased measure of an employee's incentives to increase the stock price because an option's delta is relatively insensitive to differences in time-to-exercise. For most parameter values, the delta for a 5-year option is not substantially different from that of a 10-year option. For example, the delta of an at-the-money 10-year option is 0.76 for a stock with volatility of 0.3 and dividend yield of $1 \%$ when the risk-free rate is $6 \%$. The delta decreases only to 0.72 if the maturity of the option is reduced to 5 years.
} 
the weighted average exercise price is unbiased and highly correlated with the delta that would be computed if the underlying portfolio structure were known (Core and Guay, 1999b). To estimate the incentives from total options outstanding at the end of the year, we use the method described in Core and Guay (1999b). The essence of this method is first to calculate the delta provided by the most recent grant and then to calculate the delta of the remainder of the portfolio as if it were a single grant. The delta of the total portfolio is the sum of these two values. The portfolio, grant, and exercise are all valued using the year-end stock price.

We examine two measures of option incentives and one measure of the proportion of incentives held by non-executive employees. The two option incentive measures are the logarithm of the level of incentives held by non-executive employees and the logarithm of the average level of incentives per employee (i.e., total non-executive incentives divided by total number of employees). ${ }^{4}$ The second of these incentive measures is a proxy for the average employee's wealth change for a percentage change in firm value, and the first measure is a proxy for the wealth change of all the non-executive employees for a percentage change in firm value. ${ }^{\square}$ Our third measure of options use is the proportion of incentives held by non-executive employees as a fraction of the total option incentives to all employees.

\footnotetext{
${ }^{14}$ In addition to our measure of average incentives per employee, it would be interesting to examine the average incentives per employee covered by the option plan. However, this data is not publicly available. In Section 4.4, we discuss this limitation and present sensitivity analysis using data on our sample firms that grant options to more than $50 \%$ of their employees.

${ }^{15}$ In contrast to our measure of equity incentives as the dollar change in employee wealth for a percentage change in firm value, many prior researchers on CEO equity incentives focus on fractional ownership measured as the dollar change in CEO wealth for a dollar change in firm value (e.g., Jensen and Murphy, 1990; Yermack, 1995). While there is debate over the appropriateness of alternative measures of CEO incentives (Haubrich, 1994; Baker and Hall, 1998; and Core and Guay, 1999a), the Jensen-Murphy-Yermack fractional ownership measure seems less appropriate for a group of lower-level employees, each of whom owns only a very small fraction of the firm. However, our reported results are qualitatively similar if we estimate Equations (1), (2), and (3) using the fractional ownership measure as the dependent variable.
} 


\section{Results}

\subsection{The level of equity incentives}

Tables 3 and 4 present descriptive statistics for the incentive measures and their hypothesized determinants, respectively. In Panel A of Table 3, the median change in the value of options held by non-executive employees for a $1 \%$ change in stock price is $\$ 264,723$. This variable is substantially skewed (mean $=\$ 1,294,686$ ) and, as discussed above, we use the logarithmic transformation of this measure in our tests. The log of option incentives is much less skewed, with a mean of 12.57 and median of 12.49 . To mitigate the influence of outliers, the upper- and lower-most percentiles for each independent and explanatory variable are set equal to the values at the $1^{\text {st }}$ and $99^{\text {th }}$ percentiles in each year, respectively. Panel B of Table 3 reports that correlations between our measures of option incentives range from 0.21 to 0.56 . We report descriptive statistics on the explanatory variables in Table 4.

In Columns 1 and 2 of Table 5, we present OLS results for our two measures of incentives provided to non-executive employees. Because we have multiple time-series observations per firm, we calculate t-statistics based on Huber-White robust standard errors, which are a generalization of the White (1980) standard errors that are robust to both serial correlation and heteroskedasticity (Rogers, 1993). We include twenty-two indicator variables to control for industry effects in each model. Although the residuals we use in estimating Equations (2) and (3) are based on individual annual regressions, for parsimony, we present in Table 5 the results of regressions pooled over the three sample years from 1994 to 1996 with year indicator variables.

The results in Table 5 support the incentive theory outlined in Section 2.1. Firms with greater monitoring costs and greater growth options (as proxied by firm size, the book-to-market 
ratio and $R \& D$ expense) provide greater option incentives to non-executive employees ${ }^{\square}$ The positive coefficients on $\log (\mathrm{MV}$ assets) in Columns 1 and 2 are significantly less than one, indicating that the level of incentives provided to non-executives increase at a decreasing rate with firm size. Controlling for the number of employees, the results on firm size are consistent with our prediction that there are economies of scale in monitoring, and that equity compensation increases at a decreasing rate with firm size. There is a positive and significant association between option incentives and growth options per employee in Columns 1 and 2, indicating that firms use non-executive options more intensively when human capital is a relatively more important factor of production. As predicted, in Columns 1 and 2 there is a positive relation between option incentives and $\log$ (idiosyncratic risk), our proxy for noise in the operating environment. Consistent with our prediction, when firm-specific factors result in above average optionholdings by top-five executives, lower-level employees also hold above average quantities of options.

The dependent variable in the Column 3 regression is the proportion of total option incentives given to non-executives. This variable is interpreted as a measure of how intensively firms use options for non-executive employees relative to how intensively they use options for top executives. Consistent with larger firms being more decentralized and delegating decision rights deeper into the organization, we find that non-executive employees hold a larger fraction of total option incentives as firm size and the number of employees increase. The fraction of incentives held by non-executive employees also has a significant negative association with the book-to-market ratio and a positive association with R\&D expense. These results are consistent

\footnotetext{
${ }^{16}$ By including both the market-to-book ratio and $R \& D$ expense as proxies for growth options, we potentially introduce multicollinearity that causes individual t-statistics to be understated. F-tests reject the exclusion of either or both variables. In Section 4.4, we note that our qualitative inference is unaffected if we use book-to-market (or $\mathrm{R} \& \mathrm{D}$ expense) as the sole proxy for growth options.
} 
with the interpretation that decision rights, and therefore equity incentives, are pushed deeper into the organization when growth opportunities are more important, after controlling for firm size.

Finally, we find mixed results related to segment diversification and intersegment sales. Consistent with the prediction and results of Bushman, Indjejikian, and Smith (1995), we find a negative (positive) association between segment diversification (intersegment sales) and option incentives for lower-level employees in all three columns, but this association is only significant in Column 2 (Columns 1 and 2). There is no consistent relation between option incentives and geographic diversification.

\section{2. $\quad$ Grants of option incentives}

Our hypothesis predicts that grants and exercises of option incentives are determined simultaneously. As such, we estimate a simultaneous model of grants and exercises using twostage least squares. We assume that the grant and exercise variables are endogenous and that the remaining explanatory variables are exogenous. We identify the model by exclusion restrictions. Comparing Equations (2) and (3), the seven variables related to financing costs, need for capital, and ability to borrow are expected to be related to grants but not exercises. Similarly, the four variables related to the Black-Scholes value captured by exercise, psychological reference points, and future returns are expected to be related to exercises but not grants. Although three-stage least squares has the potential to provide more efficient estimates, we use two-stage least squares to avoid transferring any mis-specification that could occur in one equation into the other equation. Descriptive statistics for the independent variables are presented in Table 6.

\footnotetext{
${ }^{17}$ If geographic diversity is dropped from the regression, the coefficient on total diversification becomes significant in Column 3, and inference on the remaining coefficients in all three columns is unaffected.
} 
In Table 7, we find strong evidence that stock option grants are more heavily used by companies with cash constraints, high capital needs, and high costs of accessing capital markets. Again, because we have multiple time-series observations per firm, we calculate t-statistics based on Huber-White robust standard errors. The explanatory power of both models is quite large, with an adjusted R-squared of $73.9 \%$ in Column 1 and $67.3 \%$ in Column 2. Consistent with the hypothesis that cash-constrained firms grant options more extensively to non-executive employees, we find significant positive coefficients on cash flow shortfall. The coefficient in Column 1 (Column 2) indicates that if a firm has a cash flow shortfall one standard deviation greater than average, its option grant is approximately $20 \%(11 \%)$ larger than average. ${ }^{18}$ Further, in support of the hypothesis that firms with high capital needs or high financing costs grant more options, the coefficients on book-to-market and R\&D expense are of the predicted sign and significant. The interest burden coefficients are positive and significant, providing support for both the cash constraint and earnings constraint hypotheses. The coefficients on the indicator variable for firms with long-term debt are of the predicted signs, but are not significant. ${ }^{10}$ Table 7 also indicates that the level of option grants to non-executive employees is lower for firms with high marginal tax rates, and is positively related to contemporaneous performance.

\footnotetext{
${ }^{18}$ While the delta (the sensitivity of option value to stock price) is the appropriate variable for testing our hypotheses about option incentives, the option value is the appropriate variable for testing our hypotheses that firms use option grants for financing purposes. All of our results in Table 7 are robust to estimating Equations (1), (2), and (3) using the Black-Scholes value of the options, instead of the option delta.

${ }^{19}$ An F-test rejects the restriction that the coefficients on both long-term debt and interest burden are zero. If the indicator variable for long-term debt is dropped from the regression, the coefficients on interest burden are more significant, and the inference on the remaining coefficients is unaffected. Conversely, if interest burden is dropped from the regression, the inference is unchanged on the remaining variables, and the coefficient on long-term debt remains insignificant.

${ }^{20}$ Results are unaffected if we drop the dummy variable for low marginal tax rate from the regression. We also obtain similar results (on a smaller sample because of missing data) if we use Graham's (1996) simulated marginal tax rates.
} 
The models in Table 7 provide mixed evidence on the hypothesis that firms manage incentive levels for non-executive employees toward a target level. The coefficient on contemporaneous exercises is positive in both Columns 1 and 2, and is significant in Column 1.21 Although not tabulated, a more direct test indicates that when lagged option exercises (i.e., option exercises in year $t-1)$ is included instead of contemporaneous exercises, its coefficient is significantly positive in both columns, which provides evidence that grants are larger following larger exercises. Thus, there is some evidence that firms make additional grants to reinstate equity incentives lost through options exercise. However, in contrast to our prediction, the association between the year $t-1$ incentive residual from Equation (1) and new incentive grants is positive and significant. This positive association suggests that firms with unusually large nonexecutive option plans make unusually large option grants to non-executives.

As described in Section 2.2, a positive correlation can be induced between the incentive residuals estimated at year $t-1$ and option incentives granted in year $t$ if the same important firmspecific determinants of non-executive option plans are omitted both from Equations (1) and (2). While the explanatory power of our two models is quite high, the possibility remains that firmspecific factors, such as the willingness of employees to accept options as a component of compensation, or firm-specific cash constraints, are omitted from Equations (1) and (2). ${ }^{2}$ An

\footnotetext{
${ }^{21}$ Note that the form of the option exercise variable varies across the columns to match the form of the dependent variable. For example, in Column 2 exercises are measured as log of incentives exercised per employee since the dependent variable is log of incentives granted per employee. We also appropriately match the dependent and independent variables in the analysis of option exercises that follows in Section 4.3.

${ }^{22}$ Even though we control for growth opportunities in the Equation (1), it is conceivable that the use of option incentives is fundamentally different for high-growth firms. To explore this possibility, we split the sample based on four proxies for differences in growth: (1) low / high book-to-market; (2) no / positive R\&D expense; (3) large / small market value of assets; and (4) NASDAQ (20\% of our sample) / non-NASDAQ firms. We then estimate Equations (1) and (2) for each of the two groups. In each of the four cases, we find that the coefficient on the incentive residual is positive and significant in Equation (2) for both high- and low-growth firms. Thus, any misspecification in Equation (1) does not appear to be due to forcing the high- and low-growth firms to have the same coefficients in the pooled regression.
} 
alternative explanation for an omitted firm-specific factor is that firms' option plans for nonexecutives are not yet at equilibrium. This lack of equilibrium is plausible given that options use for lower-level employees has grown rapidly in recent years, and that firms continue to extend options deeper into the organization. One scenario that is consistent with our results is a type of leader/follower game in which firms gradually decide to grant options deeper into the organization, and the firms that began this process earlier have more options outstanding and make larger grants each year. In this case, firms that have previously granted options to a large fraction of their employees are expected to have large residuals in year $t-1$ and large grants in year $t$, leading to a positive bias in the relation between the year $t-1$ residuals and year $t$ option grants.

\subsection{Exercises of option incentives}

The option exercise results in Table 8 support the findings in Heath, Huddart and Lang (1999) that option exercises are related to both rational economic factors as well as to psychological factors that are hard to explain within the context of rationality. The significant positive coefficient of 0.96 on log of option grants in Column 1 indicates that a $10 \%$ higher than average grant results in exercises that are $9.6 \%$ higher than average. This result is consistent with risk-averse employees actively managing their exposure to stock price risk by exercising a larger number of options when they receive larger grants of options. Note that even though a $10 \%$ greater than average option grant induces exercises that are $9.6 \%$ greater than average, most firms' option plans have grown substantially over the sample period because, on average, the number of options granted has been about twice as large as the number of options exercised.

The significant positive coefficient on the incentive residual is also consistent with exercises being influenced by employee risk-aversion. That is, when firms impose a greater than 
average level of incentive risk on their employees, the employees respond by exercising more of their portfolio of options. We find strong evidence that option exercises are greater when the realizable value of the option portfolio captures a greater percentage of the Black-Scholes value, indicating that non-executive employees recognize that it is costly to exercise options early because it involves forfeiting the time value of the option.

We find strong support for the HHL prediction that option holders set reference points with respect to stock price levels over the previous year. Option exercises are significantly positively related to the number of months within the current year that the stock price hit a 12month high, and significantly negatively related to the number of months within the current year that the stock price hit a 12-month low. This finding is difficult to explain within the context of rationality because these reference point variables load in the regression even in the presence of variables that capture the expected influence of stock price movements on optimal exercise practices (i.e., the recent stock return and the extent to which the average option held is in the money). ${ }^{2}$ A potential explanation for this finding is that our reference point variables are correlated with measurement error in our proxies for the effect of stock returns on exercise behavior. For example, a firm can have an annual return of $0 \%$ and yet the stock price can still hit several 12-month highs or lows during the year which trigger higher or lower than average exercises. When we include 11 annual rolling returns by month in the regression to control for this potential measurement error, the inference with respect to the reference point variables is unchanged.

\footnotetext{
${ }^{23}$ If volatility influences the exercise behavior of risk-averse employees, it is possible that the interpretation of our two reference point measures is confounded by their correlation with stock return volatility. However, the inclusion of return volatility in the exercise regression as an additional explanatory variable does not affect our inference.
} 
We find a significant positive relation between option exercises and stock return in the previous year. This result is consistent with risk-averse employees exercising more options when a run-up in stock price pushes their options further into the money, thereby increasing the exposure of the employees' wealth to changes in stock price. Finally, we find no evidence that option exercises by non-executives reflect private information about future returns. The coefficient on future returns is insignificant in both columns.

\subsection{Sensitivity Analyses}

Our findings are robust to a number of different specifications. We obtain qualitatively the same results in Tables 5, 7, and 8 if: (i) we use $\log$ (sales) or $\log$ (MV of equity) instead of $\log (\mathrm{MV}$ assets) as a proxy for firm size in Equation (1) or, (ii) we use only book-to-market as a proxy for growth options (and drop R\&D expense) from Equations (1) and (2). If we use only R\&D expense as a proxy for growth options (and drop book-to-market) in Equations (1) and (2), we obtain qualitatively the same results in Tables 5 and 8, and the inference with respect to growth opportunities and cash constraints in Table 7 remains the same. However, in the grant regression, the coefficient on the long-term debt indicator gains significance, and the coefficients on interest burden and high marginal tax rate lose significance.

One shortcoming of our options data is that although we can compute the total number of options granted to all employees, the number of employees to whom options are actually provided is rarely disclosed. Recall that we gather our data from firms' 10-Ks and proxy statements, and beyond aggregate option plan data, there is no requirement that firms describe details about their granting practices with respect to non-executives. ${ }^{64}$ Because we do not know

\footnotetext{
${ }^{24}$ To check whether information is available on broad-based options use by our sample firms, we randomly select twenty firms and use electronic keyword searches of their 1997 10-Ks and proxies for any discussion of the number or proportion of employees that have options. None of the firms in this sample give specific information on the proportion of their employees to whom they grant options, although some firms indicated that they have option
} 
the proportion of all employees that receive options, we have a potential problem with our measures of option incentives per employee. To see this problem, consider two firms that have the same number of options outstanding, but Firm A grants options to $10 \%$ of its employees and Firm B grants options to $100 \%$ of its employees. Since Firm A grants 10 times more options to each employee covered by the option plan, the incentives per covered employee is much greater at Firm A. However, because we cannot identify this difference in our data, our measures of incentives per employee would be identical for Firms A and B.

To ensure that this problem does not affect our inference, we match our sample to a list of companies that grant options to a majority of their employees. This list, compiled by the National Center of Employee Ownership (NCEO, 2000) from surveys and from firms' announcements of broad-based option programs, enables us to construct additional tests of our hypotheses that are not possible using data disclosed in the 10-Ks and proxy statements. However, we recognize that the NCEO variable has limitations. First, the list likely includes firms that adopted broad-based option plans after 1997. Second, the survey data gathered by consulting firms potentially reflects response biases related to size and industry, and biases related to the consultants' marketing incentives. The advantage of this data is that it is publicly available to anyone who wishes to purchase it, and the NCEO has a reputational interest in the quality of the data. Accordingly, we believe that this measure of broad-based option plan use is the best measure that is available for our broad sample.

We first examine whether the decision to provide options to a greater proportion of employees is consistent with our theory described in Section 2.1. We estimate a probit model where the dependent variable is an indicator variable equal to one if our sample firm is on the

plans that cover non-executives. 
NCEO list of firms that provide options to a majority of their employees, and zero otherwise ("the majority option indicator"). Approximately $16 \%$ of our sample firms appear on this list. ${ }^{2.5}$ The independent variables in this probit model are the same as in Table 5. In untabulated results, we find that, consistent with our previous findings, firms that provide options to a majority of their employees are larger, have greater growth opportunities, and use options more intensively for their top 5 executives. In contrast to our previous results, the coefficient on growth options per employee is not significant.

To test whether our lack of data on the proportion of employees covered causes inference problems in our earlier tests, we add the majority option indicator to our regression estimations of the levels model in Equation (1) and of the grant model in Equation (2). An insignificant coefficient on this variable indicates that the measurement problem described above is prevalent in our data, i.e., total option incentives do not, on average, increase with the proportion of total employees covered under the plan. By contrast, a positive and significant coefficient on the majority option variable indicates that, on average, when a firm chooses to provide options incentives to more employees, it increases the total amount of option incentives outstanding.

Because the decision to grant options to a majority of employees is endogenously determined, we follow Maddala (1983) and use an instrumental variables method that replaces the majority option indicator variable with the fitted probability from the probit model described above. ${ }^{6}$ Although the probit model contains the same regressors as Equation (1), the model is

\footnotetext{
${ }^{25}$ Consistent with the figures from the William M. Mercer survey of the 250 largest firms that we cite above (Carey and Ward, 1999), there is a $29 \%$ prevalence of broad-based plans among the largest $20 \%$ of our sample. There is a $13 \%$ prevalence of broad-based plans in the remainder of the sample.

${ }^{26}$ The instrumental variables regression specification follows Maddala (1983). If $I$ is an endogenous dummy variable, Maddala (p. 121) notes that the unconditional expectation of $y=x \beta+\gamma \mathrm{I}+\varepsilon$ is equal to $x \beta+\gamma p \operatorname{prob}(\mathrm{I}=1)$. To see this, note that $E[y]=\operatorname{prob}(I=1)(x \beta+\gamma I+E[\varepsilon \mid I=1])+\operatorname{prob}(I=0)(x \beta+E[\varepsilon \mid I=0])=x \beta+\gamma p \operatorname{prob}(I=1)+E[\varepsilon]=x \beta+$ $\gamma \operatorname{prob}(\mathrm{I}=1)$.
} 
identified because the fitted probability is a non-linear function of these regressors (Maddala, 1983, p. 121). When the instrumental variable is added to Equation (1), its coefficient is positive and significant and none of the inference from Table 5 changes. When the new residual from the adjusted Equation (1) specification and the instrumental variable are added to Equation (2), the coefficient on the instrumental variable is positive and significant. The inference from the model is unchanged with respect to the importance of cash flow constraints and growth opportunities, but the coefficients on R\&D expense and high marginal tax rate lose significance. Overall, these findings suggest that our inability to observe the actual proportion of employees that receive options does not affect our inference described above.

Finally, we recognize that other equity incentive mechanisms exist that are potential substitutes for employee stock options. A restricted stock plan is one such mechanism. An employee stock ownership plan (ESOP) is another. We believe that our use of the top 5 incentive residual in the regressions serves to control for the use of these alternative means, but as a sensitivity test, we control for the existence of these plans directly with two indicator variables. The restricted stock variable is equal to one if the firm has a restricted stock plan, and zero otherwise. We infer that the firm has a restricted stock plan if restricted stock is granted to any of the top-five executives during the sample period (from Execucomp). The ESOP indicator variable is equal to one if the firm's $10-\mathrm{K}$ indicates the existence of an ESOP plan during the sample period. Again, these variables are endogenous, and we instrument the variables by replacing each indicator with the fitted probability values from probit regressions. When these instrumental variables are added as regressors to the models in Table 5, 7, and 8, their coefficients are insignificant, and they have no effect on the estimated coefficients on the other regressors. 


\section{Conclusion}

In a broad cross-section of corporations, we find evidence consistent with firms granting non-executive options for both incentive purposes and as a means of internal finance. The level of option incentives varies in a manner consistent with economic theory. As predicted, we find that the level of non-executives' option incentives is increasing in firms' growth opportunities, the relative importance of human capital as a factor of production, and firm size. Firms use nonexecutive option grants as a substitute for cash compensation to a greater extent when firms face cash flow constraints, and when the costs of external capital are greater.

We find mixed evidence that firms actively manage the level of non-executive option incentives through annual grants. In support of this hypothesis, we find that firms make additional grants to reinstate incentive effects lost through options exercise. However, in contrast to our prediction, firms that have unusually large non-executive option plans make unusually large option grants to non-executives. This finding suggests either that there exist important firmspecific reasons for granting options to non-executive employees that are not captured by our models, or that firms have not, on average, reached equilibrium in the way they provide stock option incentives to non-executives.

Our findings suggest at least two avenues for future research. First, we confirm the findings of Heath, Huddart, and Lang (1999) that the exercise practices of non-executive employees reflect psychological biases. It is not obvious how to incorporate these biases into the traditional economic assumption of a rational, effort-averse agent with a concave utility function over wealth. If individuals possess psychological biases that influence the perceived value of their options, a fruitful avenue for further research is to develop a parsimonious model for agent utility that predicts these biases, and then use this model to examine the effect of these biases on 
the incentives provided by equity compensation. A useful starting point for such a model would be similar to efforts that are being undertaken in the asset pricing literature (e.g., Odean, 1998).

While option plans for top executives have seen widespread use for decades, option plans that include employees at all levels are a relatively recent phenomena. Our research contributes to understanding why firms use employee stock options by providing large-sample evidence on options use that generally supports economic predictions. Having established these baseline large-sample results, a promising avenue for further research is to investigate smaller, more homogeneous samples to better understand the dynamics of employee option plans. For example, these samples can be used to investigate further the use of options as a financing tool, and how stock compensation fits into the "pecking order" of financing alternatives. The willingness of a firm's lower-level employees to accept options instead of cash compensation likely depends on firm-specific factors such as the payoff they or their co-workers have received from previously granted options. In turn, these firm-specific factors are likely to affect how stock option plans evolve over time. In research-in-progress, we examine the use of options for incentive and financing purposes using a sample of 240 companies with high growth opportunities and a range of needs for equity finance. 


\section{References}

Baber W., S. Janakiraman, and S. Kang, 1996, Investment opportunities and the structure of executive compensation, Journal of Accounting and Economics 21, 297-318.

Baker, G. and B. Hall, 1998, CEO incentives and firm size, NBER Working paper 6868.

Black, F. and M. Scholes, 1973, The pricing of options and corporate liabilities, Journal of Political Economy 81, 637-654.

Bushman, R. Indjejikian, R. and A. Smith, 1995, Aggregate performance measures in business unit manager compensation: The role of intrafirm interdependencies. Journal of Accounting Research. 33 (Supplement): 101-128.

Carey, A. and S. Ward, 1999, Stock options trickle down, USA Today, Source: William M. Mercer.

Core, J. and W. Guay, 1999a, The use of equity grants to manage optimal equity incentive levels, Journal of Accounting and Economics 28, 151-184.

Core, J. and W. Guay, 1999b, Estimating the value of stock option portfolios and their sensitivities to price and volatility. Working paper, University of Pennsylvania.

Core, J. and J. Qian, 2000, Option-like contracts for innovation and production, Working paper, University of Pennsylvania.

Dechow, P., A. Hutton, and R. Sloan, 1996, Economic consequences of accounting for stockbased compensation Journal of Accounting Research 34, 1-20.

Demsetz, H. and K. Lehn, 1985, The structure of corporate ownership: causes and consequences. Journal of Political Economy , 1155-1177.

Frye, M., 1999, Equity-Based Compensation for Employees: Firm Performance and Determinants, working paper, Georgia Institute of Technology.

Graham, John R., 1996, Proxies for the corporate marginal tax rate, Journal of Financial Economics 42, 187-221.

Hale, Jamie, 1998, Strategic rewards: Keeping your best talent from walking out the door, Compensation \& Benefits Management 14(Summer), 39-50.

Hall, B. and J. Liebman, 2000, The taxation of executive compensation, NBER working paper 7596.

Hall, B. and J. Liebman, 1998, Are CEOs really paid like bureaucrats?, The Quarterly Journal of Economics 103, 653-691. 
Haubrich, J., 1994, Risk-aversion, performance pay, and the principal-agent problem, Journal of Political Economy 102, 258-276.

Heckman, J., 1979. Sample selection bias as a specification error, Econometrica 47, 153-61.

Himmelberg, C., G. Hubbard, and D. Palia, 1999, Understanding the determinants of managerial ownership and the link between ownership and performance, Journal of Financial Economics 53, 353-384.

Heath, C., S. Huddart, and M. Lang, 1999, Psychological factors and stock option exercise, Quarterly Journal of Economics 114, 601-628.

Huddart, S., 1994, Employee stock options, Journal of Accounting and Economics 18, 207-231.

Huddart, S., and M. Lang, 1996, Employee stock option exercises: an empirical analysis, Journal of Accounting and Economics 21, 5-43.

Hymowitz, C. and M. Murray, 1999, Raises and praise or out the door: How GE's chief rates and spurs his employees, The Wall Street Journal (June 21), B1.

Janakiraman, S., 1998, Stock option awards and exercise behavior of CEOs: An empirical analysis, Working paper, University of Texas at Dallas.

Jensen and Meckling 1992, Specific and general knowledge, and organizational structure, in Contract Economics, L. Werin and H. Wijkander, eds. Basil Blackford, Oxford, 251-274.

Jensen, M. and K. Murphy, 1990, Performance pay and top-management incentives, Journal of Political Economy 98, 225-264.

Keating, A. S., 1997, Determinants of divisional performance evaluation practices, Journal of Accounting and Economics 24, 243-273.

Kole, S., 1997, The complexity of compensation contracts, Journal of Financial Economics 43, 79-104.

Lambert, R., Larcker, D., Verrecchia, R., 1991. Portfolio considerations in valuing executive compensation. Journal of Accounting Research 29, 129-149.

Maddala, G. S., 1983, Limited dependent and qualitative variables in econometrics. Cambridge University Press, Cambridge.

Matsunaga, S., 1995, The effects of financial reporting costs on the use of employee stock options. The Accounting Review 70, 1-26. 
Merton, R., 1973, Theory of rational option pricing, Bell Journal of Economics and Management Science 4, 141-183.

Miller, M. and M. Scholes, 1980, Executive compensation, taxes, and incentives. Working paper, University of Chicago.

National Center for Employee Ownership, 2000, Stock options companies list (companies offering stock options to most or all employees). National Center for Employee Ownership, Oakland, CA.

Odean, T., 1998, Are investors reluctant to realize their losses, Journal of Finance 53, 17751798.

Plesko, G., 1999, An evaluation of alternative measures of corporate tax rates. Working paper, Massachusetts Institute of Technology.

Rogers, W., 1993, Regression standard errors in clustered samples, Stata Technical Bulletin Reprints, vol. 3. College Station, Texas. Stata Press, 83-94.

Smith, C. and R. Watts, 1982, Incentive and tax effects of executive compensation plans, Australian Journal of Management, 139-157.

Smith, C. and R. Watts, 1992, The investment opportunity set and corporate financing, dividends, and compensation policies, Journal of Financial Economics 32, 263-292.

Vargus, M., 1998, Determinants of executives' decisions to bailout of stock options, Working paper, University of Southern California.

White, H., 1980. A Heteroskedasticity-consistent covariance matrix estimator and a direct test for heteroskedasticity, Econometrica 48, 817-838.

Yermack, D., 1995, Do corporations award CEO stock options effectively?, Journal of Financial Economics 39, 237-269. 
Table 1

Summary of hypotheses regarding the determinants of grants, exercise, and holdings of options by non-executive employees

\section{Level of option incentives}

\begin{tabular}{lc}
\hline \hline Hypothesized determinant & Predicted association \\
\hline Size / decentralization & $+/-$ \\
Idiosyncratic risk & + \\
Growth opportunities & + \\
Top executive option intensity & + \\
Importance of human capital & + \\
Diversification & - \\
$\quad$ Option grants & Predicted association \\
\hline Hypothesized determinant & + \\
\hline Cash flow shortfall & + \\
Information asymmetry & - \\
Ability to borrow / sell debt & - \\
Marginal tax rate & - \\
Lagged residual from levels model & \\
Contemporaneous exercises (simultaneous) & + \\
Contemporaneous performance & + \\
\hline
\end{tabular}

\section{Option exercises}

\begin{tabular}{lc}
\hline Hypothesized determinant & Predicted association \\
\hline Contemporaneous grants (simultaneous) & + \\
Realizable value / option value & + \\
Current and lagged return & $?$ \\
Price hits high & + \\
Price hits low & - \\
Future return & - \\
\hline \hline
\end{tabular}


Table 2

Summary statistics

\section{Panel A: Summary statistics for non-executive employee stock option plans}

\begin{tabular}{|c|c|c|c|c|c|c|c|}
\hline & Mean & Std. dev. & Minimum & Q1 & Median & Q3 & Maximum \\
\hline \multicolumn{8}{|l|}{ Total options outstanding } \\
\hline $\begin{array}{l}\text { Number of options outstanding scaled by } \\
\text { shares outstanding }\end{array}$ & $6.9 \%$ & $5.3 \%$ & $0.01 \%$ & $3.2 \%$ & $5.5 \%$ & $9.2 \%$ & $37.0 \%$ \\
\hline $\begin{array}{l}\text { Black-Scholes value of options } \\
\text { outstanding scaled by MV equity }\end{array}$ & $3.7 \%$ & $3.8 \%$ & $0.01 \%$ & $1.2 \%$ & $2.5 \%$ & $4.9 \%$ & $24.1 \%$ \\
\hline \multicolumn{8}{|l|}{ Non-executive options outstanding } \\
\hline $\begin{array}{l}\text { Fraction of total options outstanding held } \\
\text { by non-executives }\end{array}$ & $66.9 \%$ & $18.7 \%$ & $0.01 \%$ & $55.7 \%$ & $69.4 \%$ & $81.5 \%$ & $100.0 \%$ \\
\hline $\begin{array}{l}\text { Number of options held by non-executives } \\
\text { scaled by shares outstanding }\end{array}$ & $4.5 \%$ & $3.6 \%$ & $0.01 \%$ & $2.0 \%$ & $3.5 \%$ & $6.0 \%$ & $28.7 \%$ \\
\hline $\begin{array}{l}\text { Black-Scholes option portfolio value per } \\
\text { non-executive employee }\end{array}$ & $\$ 17,296$ & $\$ 54,478$ & $\$ 0.1$ & $\$ 1,044$ & $\$ 3,143$ & $\$ 10,109$ & $\$ 1,226,819$ \\
\hline
\end{tabular}

The sample consists of 2,349 firm-year observations from 1994 to 1997. Options are valued using the Black-Scholes (1973) model, as modified by Merton (1973) to account for dividend payouts. 
Panel B: Industry median values for non-executive employee stock option plans

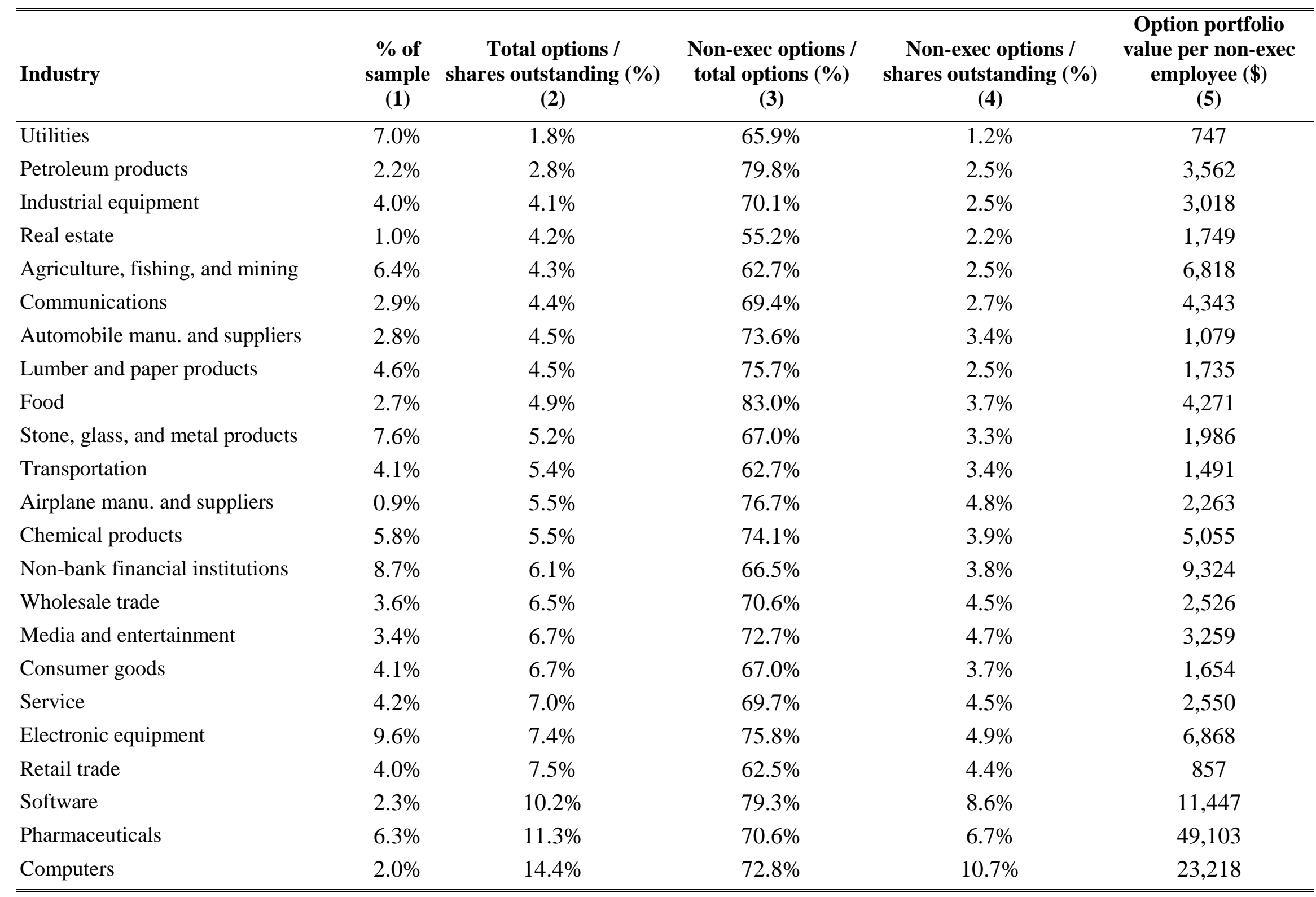


Table 3

Summary statistics for the level of non-executive equity incentives

from stock option plans and their determinants

\section{Panel A: Descriptive statistics}

\begin{tabular}{lccccc}
\hline \hline \multicolumn{1}{c}{ Variable } & Mean & Std Dev & Q1 & Median & Q3 \\
\hline Option incentives & $1,294,686$ & $3,262,589$ & 85,314 & 264,723 & 919,650 \\
Log of option incentives & 12.57 & 1.73 & 11.35 & 12.49 & 13.73 \\
$\begin{array}{l}\text { Option incentives per employee } \\
\text { Log of option incentives per employee }\end{array}$ & 219.44 & 511.21 & 20.19 & 55.94 & 158.83 \\
& 4.09 & 1.59 & 3.01 & 4.02 & 5.07 \\
$\begin{array}{l}\text { Fraction of total options outstanding } \\
\text { held by non-top-five employees }\end{array}$ & $68.41 \%$ & $19.68 \%$ & $56.16 \%$ & $71.17 \%$ & $83.85 \%$ \\
\hline \hline
\end{tabular}

Panel B: Correlation matrix

(correlations with an absolute value greater than 0.045 are significant at a 0.05 level)

\begin{tabular}{lccc}
\hline \hline \multicolumn{1}{c}{ Variable } & & & \\
\hline Log of option incentives & 1.00 & & \\
Log of option incentives per employee & 0.48 & 1.00 & 1.00 \\
$\begin{array}{l}\text { Fraction of total options outstanding } \\
\text { held by non-top-five employees }\end{array}$ & 0.56 & 0.21 & \\
\hline \hline
\end{tabular}

The sample consists of 1,694 firm-year observations from 1994 to 1996 . Non-executive option plan incentives is the sensitivity of the total value of stock options held by non-top-five employees to a $1 \%$ change in stock price. Options are valued using the Black-Scholes (1973) model, as modified by Merton (1973) to account for dividend payouts. 
Table 4

Summary statistics for the determinants of the level of non-executive equity incentives from stock option plans

\begin{tabular}{lccccc}
\hline \hline \multicolumn{1}{c}{ Variable } & Mean & Std Dev & Q1 & Median & Q3 \\
\hline Log(MV assets $)_{\mathrm{t}-1}$ & 20.89 & 1.52 & 19.73 & 20.79 & 21.90 \\
Log(\# of employees $)_{\mathrm{t}-1}$ & 8.49 & 1.73 & 7.49 & 8.53 & 9.68 \\
Log(idiosyncratic risk $)_{\mathrm{t}-1}$ & -1.32 & 0.45 & -1.66 & -1.37 & -1.01 \\
Book-to-market $\mathrm{t}_{\mathrm{t}-1}$ & 0.65 & 0.24 & 0.48 & 0.67 & 0.84 \\
R\&D $_{\mathrm{t}-1}$ & 0.04 & 0.07 & 0.00 & 0.00 & 0.05 \\
Growth options per employee $_{\mathrm{t}-1}$ & 0.32 & 0.56 & 0.04 & 0.12 & 0.31 \\
Total diversification $_{\mathrm{t}-1}$ & 0.70 & 0.54 & 0.24 & 0.63 & 1.09 \\
Intersegment sales $_{\mathrm{t}-1}$ & 0.01 & 0.03 & 0.00 & 0.00 & 0.00 \\
Geographic diversification $_{\mathrm{t}-1}$ & 0.35 & 0.41 & 0.00 & 0.00 & 0.69
\end{tabular}

The sample consists of 1,694 year observations from 1994 to 1996. $\log (\mathrm{MV}$ of assets) is the logarithm of the market value of the firm's equity plus the book value of the firm's liabilities. $\log$ (\# of employees) is the logarithm of the number of employees. $\log$ (idiosyncratic risk) is the logarithm of the standard deviation of the residual from a market model regression estimated over 36 months of returns ending with the fiscal year-end (subject to a minimum of 12 monthly returns). Bookto-market is (book value of assets) / (book value of liabilities + market value of equity). R\&D is the three-year average of research and development expense scaled by assets. Growth options per employee is (market value of equity - book value of equity) / number of employees (in millions of dollars). Total diversification is an entropy measure of total product diversification calculated from data on the Compustat Industry Segments File and equal to $\Sigma P_{i} \ln \left(1 / P_{i}\right)$ where $P_{i}$ is dollar sales of principal product $i$ scaled by total firm sales. Intersegment sales is interindustry segment sales scaled by total net sales. Geographic diversification is an entropy measure of geographic diversification calculated from data on the Compustat Geographic Segments File and equal to $\Sigma G_{i} \ln \left(1 / G_{i}\right)$ where $G_{i}$ is dollar sales represented by geographic segment $i$ scaled by total firm sales. 
Table 5

Determinants of the level of non-executive equity incentives from employee stock option plans

\begin{tabular}{|c|c|c|c|c|}
\hline \multirow[b]{2}{*}{$\begin{array}{l}\text { Independent } \\
\text { variable }\end{array}$} & \multirow[b]{2}{*}{$\begin{array}{l}\text { Predicted } \\
\text { sign }\end{array}$} & \multicolumn{3}{|c|}{ Dependent variable } \\
\hline & & $\begin{array}{c}\text { Log of option } \\
\text { plan incentives } \\
\text { (1) }\end{array}$ & $\begin{array}{c}\text { Log of option } \\
\text { plan incentives } \\
\text { per employee } t-1 \\
(2) \\
\end{array}$ & $\begin{array}{c}\text { Fraction of } \\
\text { incentives held } \\
\text { by non-execs } \\
(3) \\
\end{array}$ \\
\hline $\log (\mathrm{MV} \text { assets })_{\mathrm{t}-1}$ & $+/-$ & $\begin{array}{c}0.73 \\
(16.20)\end{array}$ & $\begin{array}{l}0.10 \\
(3.64)\end{array}$ & $\begin{array}{c}0.02 \\
(1.82)\end{array}$ \\
\hline $\log (\# \text { of employees })_{t-1}$ & $+/-$ & $\begin{array}{c}0.21 \\
(4.52)\end{array}$ & & $\begin{array}{c}0.05 \\
(4.85)\end{array}$ \\
\hline $\log (\text { idiosyncratic risk })_{\mathrm{t}-1}$ & + & $\begin{array}{c}0.38 \\
(4.29)\end{array}$ & $\begin{array}{c}0.44 \\
(4.09)\end{array}$ & $\begin{array}{c}-0.0013 \\
(-0.06)\end{array}$ \\
\hline Book-to-market $_{\mathrm{t}-1}$ & - & $\begin{array}{c}-2.03 \\
(-12.02)\end{array}$ & $\begin{array}{c}-1.90 \\
(-9.40)\end{array}$ & $\begin{array}{c}-0.13 \\
(-3.68)\end{array}$ \\
\hline $\mathrm{R} \& \mathrm{D}_{\mathrm{t}-1}$ & + & $\begin{array}{l}2.98 \\
(6.21)\end{array}$ & $\begin{array}{c}3.52 \\
(6.60)\end{array}$ & $\begin{array}{c}0.29 \\
(2.96)\end{array}$ \\
\hline Growth options per employee $_{t-1}$ & + & $\begin{array}{c}0.0002 \\
(3.10)\end{array}$ & $\begin{array}{l}0.0011 \\
(14.13)\end{array}$ & $\begin{array}{c}0.00003 \\
(1.82)\end{array}$ \\
\hline Total diversification $_{\mathrm{t}-1}$ & - & $\begin{array}{c}-0.05 \\
(-0.73)\end{array}$ & $\begin{array}{c}-0.20 \\
(-2.79)\end{array}$ & $\begin{array}{c}-0.02 \\
(-1.51)\end{array}$ \\
\hline Intersegment sales $\mathrm{t}_{\mathrm{t}-1}$ & + & $\begin{array}{c}2.20 \\
(3.36)\end{array}$ & $\begin{array}{l}2.15 \\
(3.01)\end{array}$ & $\begin{array}{c}0.23 \\
(1.07)\end{array}$ \\
\hline Geographic diversification $_{\mathrm{t}-1}$ & - & $\begin{array}{c}0.14 \\
(1.88)\end{array}$ & $\begin{array}{c}-0.04 \\
(-0.48)\end{array}$ & $\begin{array}{c}-0.02 \\
(-1.18)\end{array}$ \\
\hline Top 5 option residual $_{\mathrm{t}-1}$ & + & $\begin{array}{c}0.47 \\
(13.98)\end{array}$ & $\begin{array}{c}0.47 \\
(12.25)\end{array}$ & \\
\hline
\end{tabular}


Table 5 (continued)

Determinants of the level of non-executive equity incentives

from employee stock option plans

\begin{tabular}{|c|c|c|c|c|}
\hline \multirow[b]{2}{*}{$\begin{array}{l}\text { Independent } \\
\text { variable }\end{array}$} & \multirow[b]{2}{*}{$\begin{array}{l}\text { Predicted } \\
\text { sign }\end{array}$} & \multicolumn{3}{|c|}{ Dependent variable } \\
\hline & & $\begin{array}{c}\text { Log of option } \\
\text { plan incentives } \\
\text { (1) }\end{array}$ & $\begin{array}{c}\text { Log of option } \\
\text { plan incentives } \\
\text { per employee } \\
\text { (2) } \\
\end{array}$ & $\begin{array}{c}\text { Fraction of } \\
\text { incentives held } \\
\text { by non-execs } \\
\text { (3) } \\
\end{array}$ \\
\hline $\mathrm{N}$ & & 1,652 & 1,652 & 1,694 \\
\hline Adjusted $\mathrm{R}^{2}$ & & $81.7 \%$ & $69.3 \%$ & $25.3 \%$ \\
\hline
\end{tabular}

The sample consists of 1,694 firm-year observations from 1994 to 1996. T-statistics (in parentheses) are based on HuberWhite robust standard errors. Coefficients on an intercept, 22 industry indicator variables and two year indicator variables not shown. The regression model is described by Equation (1) in Section 2.1. All dependent variables are based on options held by non-top-five employees and are measured at time $t-1$. Non-executive option plan incentives is the sensitivity of the total value of stock options held by non-top-five employees to a $1 \%$ change in stock price. Options are valued using the Black-Scholes (1973) model, as modified by Merton (1973) to account for dividend payouts. Top 5 option residual is the residual from a regression of top-five executives' equity incentives from options on size, book-to-market, R\&D expense, and idiosyncratic risk. All other variables are defined in Table 4 . 


\section{Table 6}

\section{Summary statistics for the determinants of grants and exercises of non-executive equity incentives from stock option plans}

\begin{tabular}{|c|c|c|c|c|c|}
\hline Variable & Mean & Std Dev & Q1 & Median & Q3 \\
\hline Cash flow shortfall ${ }_{\mathrm{t}-1}$ & 0.02 & 0.08 & -0.02 & 0.01 & 0.04 \\
\hline Book-to-market $_{\mathrm{t}-1}$ & 0.64 & 0.23 & 0.47 & 0.65 & 0.83 \\
\hline $\mathrm{R} \& \mathrm{D}_{\mathrm{t}-1}$ & 0.04 & 0.07 & 0.00 & 0.00 & 0.05 \\
\hline Long-term debt indicator ${ }_{\mathrm{t}-1}$ & 0.90 & 0.30 & 1.00 & 1.00 & 1.00 \\
\hline Interest burden $_{\mathrm{t}-1}$ & 0.20 & 0.23 & 0.06 & 0.13 & 0.24 \\
\hline Low marginal tax $\mathrm{x}_{\mathrm{t}-1}$ & 0.02 & 0.15 & 0.00 & 0.00 & 0.00 \\
\hline High marginal tax $x_{t-1}$ & 0.56 & 0.50 & 0.00 & 1.00 & 1.00 \\
\hline Stock return $_{t}$ & 0.26 & 0.41 & 0.02 & 0.22 & 0.44 \\
\hline Stock return $_{\mathrm{t}-1}$ & 0.19 & 0.41 & -0.07 & 0.13 & 0.36 \\
\hline Residual $_{\text {Log of incentives model } t-1}$ & 0.04 & 0.63 & -0.35 & 0.07 & 0.44 \\
\hline Residual $_{\text {Log of incentives per employee model } t-1}$ & 0.03 & 0.78 & -0.44 & 0.04 & 0.53 \\
\hline $\log (\text { sales })_{\mathrm{t}-1}$ & 20.90 & 1.73 & 19.90 & 21.00 & 22.08 \\
\hline $\log (\# \text { of employees })_{t-1}$ & 8.62 & 1.75 & 7.59 & 8.67 & 9.79 \\
\hline Fraction of BS value realizable $\mathrm{t}_{\mathrm{t}-1}$ & 0.09 & 1.41 & 0.10 & 0.43 & 0.65 \\
\hline Number of recent price lows $s_{t}$ & 0.75 & 1.33 & 0.00 & 0.00 & 1.00 \\
\hline Number of recent price highs $s_{t}$ & 3.62 & 2.62 & 1.00 & 3.00 & 6.00 \\
\hline Stock return $_{t+1}$ & 0.15 & 0.41 & -0.10 & 0.12 & 0.35 \\
\hline
\end{tabular}

The sample consists of 1,263 firm-year observations from 1995 to 1997. Cash flow shortfall is the three-year average of [(common and preferred dividends + cash flow from investing - cash flow from operations)/total assets]. Book-to-market is (book value of assets) / (book value of liabilities + market value of equity). R\&D is the three-year average of research and development expense scaled by assets. Long-term debt indicator is an indicator variable equal to one if the firm has longterm debt outstanding, and zero otherwise. Interest burden is the three-year average of interest expense scaled by operating income before depreciation. Negative values of interest burden and values greater than one are set equal to one. Low marginal tax is an indicator variable equal to one if the firm has negative taxable income and net operating loss carryforwards in each of the three years prior to the year the new equity grant is awarded, and zero otherwise. High marginal tax is an indicator variable equal to one if the firm has positive taxable income and no net operating loss carry-forwards in each

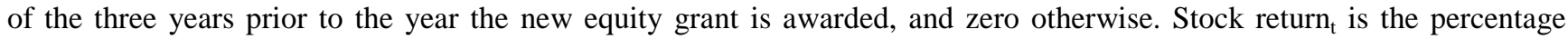
return on the firm's stock in the fiscal year in which incentives are awarded. Stock return ${ }_{t-1}$ is the percentage return on the firm's stock in the fiscal year prior to which incentives are awarded. The three incentive residuals are the residuals from regressions of the incentives from stock options on their determinants as estimated in Table 5. Log(sales) is the logarithm of the firm's sales. $\log$ (\# of employees) is the logarithm of the number of employees. Fraction of BS value realizable is equal to (beginning of year stock price minus average exercise price of options held) divided by beginning of year Black-Scholes value per option held. Number of recent price lows is the number of months within the current year that the stock price hits a 12-month low. Number of recent price highs is the number of months within the current year that the stock price hits a 12month high. Stock return $\mathrm{t}_{t+1}$ is the percentage return on the firm's stock in the fiscal year in after incentives are awarded. 
Table 7

Simultaneous estimation of non-executive equity incentive grants and exercises: Grant model

\begin{tabular}{|c|c|c|c|}
\hline \multirow[b]{2}{*}{$\begin{array}{c}\text { Independent } \\
\text { variable }\end{array}$} & \multirow[b]{2}{*}{$\begin{array}{l}\text { Predicted } \\
\text { sign }\end{array}$} & \multicolumn{2}{|c|}{ Grant model: Dependent variable } \\
\hline & & $\begin{array}{c}\text { Log of incentives } \\
\text { granted }_{t} \\
(1) \\
\end{array}$ & $\begin{array}{c}\text { Log of incentives } \\
\text { granted per } \\
\text { employee }_{t} \\
(2) \\
\end{array}$ \\
\hline Cash flow shortfall ${ }_{\mathrm{t}-1}$ & + & $\begin{array}{l}2.25 \\
(4.74)\end{array}$ & $\begin{array}{c}1.26 \\
(2.40)\end{array}$ \\
\hline Book-to-market ${ }_{\mathrm{t}-1}$ & - & $\begin{array}{c}-2.45 \\
(-8.23)\end{array}$ & $\begin{array}{c}-2.61 \\
(-7.29)\end{array}$ \\
\hline $\mathrm{R} \& \mathrm{D}_{\mathrm{t}-1}$ & + & $\begin{array}{c}2.27 \\
(3.87)\end{array}$ & $\begin{array}{c}2.81 \\
(4.57)\end{array}$ \\
\hline Long-term debt indicator ${ }_{\mathrm{t}-1}$ & - & $\begin{array}{c}-0.14 \\
(-1.17)\end{array}$ & $\begin{array}{c}-0.20 \\
(-1.36)\end{array}$ \\
\hline Interest burden $_{\mathrm{t}-1}$ & + & $\begin{array}{c}0.39 \\
(2.16)\end{array}$ & $\begin{array}{c}0.34 \\
(1.70)\end{array}$ \\
\hline Low marginal tax $x_{t-1}$ & + & $\begin{array}{c}0.37 \\
(1.90)\end{array}$ & $\begin{array}{c}-0.17 \\
(-0.92)\end{array}$ \\
\hline High marginal tax $\mathrm{x}_{\mathrm{t}-1}$ & - & $\begin{array}{c}-0.12 \\
(-1.94)\end{array}$ & $\begin{array}{c}-0.19 \\
(-2.46)\end{array}$ \\
\hline Stock return $_{\mathrm{t}}$ & + & $\begin{array}{c}0.60 \\
(4.74)\end{array}$ & $\begin{array}{c}0.62 \\
(4.35)\end{array}$ \\
\hline Stock return $_{\mathrm{t}-1}$ & + & $\begin{array}{c}-0.02 \\
(-0.30)\end{array}$ & $\begin{array}{c}-0.08 \\
(-0.84)\end{array}$ \\
\hline Incentive residual $_{\mathrm{t}-1}$ & - & $\begin{array}{c}0.39 \\
(5.10)\end{array}$ & $\begin{array}{c}0.66 \\
(6.68)\end{array}$ \\
\hline Exercises of incentives $_{t}$ & + & $\begin{array}{c}0.20 \\
(3.26)\end{array}$ & $\begin{array}{c}0.11 \\
(1.34)\end{array}$ \\
\hline
\end{tabular}


Table 7 (continued)

Simultaneous estimation of non-executive equity incentive grants and exercises: Grant model

\begin{tabular}{|c|c|c|c|}
\hline \multirow[b]{2}{*}{$\begin{array}{l}\text { Independent } \\
\text { variable }\end{array}$} & \multirow[b]{2}{*}{$\begin{array}{l}\text { Predicted } \\
\text { sign }\end{array}$} & \multicolumn{2}{|c|}{ Grant model: Dependent variable } \\
\hline & & $\begin{array}{c}\text { Log of incentives } \\
\text { granted }_{t} \\
(1)\end{array}$ & $\begin{array}{c}\text { Log of incentives } \\
\text { granted per } \\
\text { employee }_{t} \\
\text { (2) }\end{array}$ \\
\hline $\log (\text { sales })_{t-1}$ & $?$ & $\begin{array}{c}0.67 \\
(8.23)\end{array}$ & $\begin{array}{c}-0.06 \\
(-2.04)\end{array}$ \\
\hline $\log (\# \text { of employees })_{t-1}$ & $?$ & $\begin{array}{c}-0.02 \\
(-0.35)\end{array}$ & \\
\hline $\mathrm{N}$ & & 1,263 & 1,254 \\
\hline Adjusted $\mathrm{R}^{2}$ & & $73.9 \%$ & $67.3 \%$ \\
\hline
\end{tabular}

The sample consists of 1,263 firm-year observations from 1995 to 1997. T-statistics (in parentheses) are based on HuberWhite robust standard errors. Coefficients on an intercept, 22 industry indicator variables and two year indicator variables not shown. The regression model is described by Equation (2) in Section 2.2. All dependent variables are based on options granted to non-top-five employees and are measured at time $t$. Log of grants of equity incentives to non-executives (the dependent variable in Column 1) is the log of the sensitivity of the value of new stock options granted to a $1 \%$ change in stock price. Options are valued using the Black-Scholes (1973) model, as modified by Merton (1973) to account for dividend payouts. The incentive residuals used in each column are the residuals from regressions of the incentives from stock options on their determinants as estimated in Table 5. These residuals are estimated at the end of the fiscal year prior to the fiscal year in which the grant of new equity incentives is awarded. All the independent variables are defined in Table 6. The form of the Exercises of incentives variable varies across the columns to match the form of the dependent variable. For example, in Column 2 exercises are measured as log of incentives exercised per employee because the dependent variable is $\log$ of incentives granted per employee. 
Table 8

Simultaneous estimation of non-executive equity incentive grants and exercises: Exercise model

\begin{tabular}{|c|c|c|c|}
\hline \multirow[b]{2}{*}{$\begin{array}{l}\text { Independent } \\
\text { variable }\end{array}$} & \multirow[b]{2}{*}{$\begin{array}{l}\text { Predicted } \\
\text { sign }\end{array}$} & \multicolumn{2}{|c|}{$\begin{array}{c}\text { Exercise model: Dependent } \\
\text { variable }\end{array}$} \\
\hline & & $\begin{array}{c}\text { Log of incentives } \\
\text { exercised }_{t} \\
(1)\end{array}$ & $\begin{array}{c}\text { Log of incentives } \\
\text { exercised per } \\
\text { employee } \\
\text { (2) } \\
\end{array}$ \\
\hline Incentive residual $_{\mathrm{t}-1}$ & + & $\begin{array}{c}0.23 \\
(2.71)\end{array}$ & $\begin{array}{c}0.17 \\
(2.15)\end{array}$ \\
\hline Grants of incentives $t_{t}$ & + & $\begin{array}{c}0.96 \\
(15.22)\end{array}$ & $\begin{array}{c}0.99 \\
(14.22)\end{array}$ \\
\hline Fraction of BS value realizable $t_{t-1}$ & + & $\begin{array}{c}0.15 \\
(4.07)\end{array}$ & $\begin{array}{c}0.15 \\
(4.05)\end{array}$ \\
\hline Number of recent price lows $t_{t}$ & - & $\begin{array}{c}-0.19 \\
(-5.06)\end{array}$ & $\begin{array}{c}-0.17 \\
(-4.84)\end{array}$ \\
\hline Number of recent price highs $s_{t}$ & + & $\begin{array}{c}0.10 \\
(6.18)\end{array}$ & $\begin{array}{c}0.10 \\
(6.21)\end{array}$ \\
\hline Stock return $_{\mathrm{t}+1}$ & - & $\begin{array}{c}0.04 \\
(0.54)\end{array}$ & $\begin{array}{c}0.08 \\
(1.04)\end{array}$ \\
\hline Stock return $_{\mathrm{t}}$ & $?$ & $\begin{array}{c}-0.08 \\
(-0.72)\end{array}$ & $\begin{array}{c}-0.11 \\
(-0.92)\end{array}$ \\
\hline Stock return $\mathrm{t}_{\mathrm{t}-1}$ & ? & $\begin{array}{c}0.25 \\
(2.59)\end{array}$ & $\begin{array}{c}0.25 \\
(2.65)\end{array}$ \\
\hline $\log (\text { Sales })_{t-1}$ & $?$ & $\begin{array}{c}0.08 \\
(1.16)\end{array}$ & $\begin{array}{c}0.08 \\
(2.83)\end{array}$ \\
\hline $\log (\# \text { of employees })_{t-1}$ & $?$ & $\begin{array}{c}0.00 \\
(0.05)\end{array}$ & \\
\hline $\mathrm{N}$ & & 1,263 & 1,254 \\
\hline Adjusted $\mathrm{R}^{2}$ & & $76.5 \%$ & $69.4 \%$ \\
\hline
\end{tabular}

The sample consists of 1,263 firm-year observations from 1995 to 1997. T-statistics (in parentheses) are based on HuberWhite robust standard errors. Coefficients on an intercept, 22 industry indicator variables and two year indicator variables not shown. The regression model is described by Equation (3) in Section 2.3. All dependent variables are based on options exercised by non-top-five employees and are measured at time $t$. Log of exercised equity incentives to non-executives (the 
dependent variable in Column 1) is the log of the sensitivity of the value of stock options exercised to a $1 \%$ change in stock price. Options are valued using the Black-Scholes (1973) model, as modified by Merton (1973) to account for dividend payouts. The incentive residuals used in each column are the residuals from regressions of the incentives from stock options on their determinants as estimated in Table 5. These residuals are estimated at the end of the fiscal year prior to the fiscal year in which the grant of new equity incentives is awarded. All the independent variables are defined in Table 6 . The form of the Grants of incentives variable varies across the columns to match the form of the dependent variable. For example, in Column 2 grants are measured as log of incentives granted per employee because the dependent variable is log of incentives exercises per employee. 